\title{
Period of the day and food-based enrichment affect behaviour activity of Tamandua tetradactyla in captivity?
}

\author{
Gilson de Souza Ferreira Neto ${ }^{1,2}\left(\mathbb{D}\right.$, Adamo Cardoso Barros $^{2}$ (D), Tainara \\ Venturini Sobroza $^{2}$ (D), Pedro Ubatan Camargo Neves ${ }^{1}$ (D), Matthew J. Phillips ${ }^{3}$ (D) \\ \& Elizabeth Ferreira Guimarães ${ }^{4}$ (D)
}

(1) Universidade Federal de Goiás - Campus II, Instituto de Ciências Biológicas, Samambaia 74001-970, Caixa Postal 131, Goiânia, Goiás, Brazil. E-mail: pedroubatan@gmail.com

(2) Instituto Nacional de Pesquisas da Amazônia - INPA, Avenida André Araújo 2936, Petrópolis 69067375, Manaus, Amazonas, Brazil. E-mail: gilsonsouzaferreiraneto@gmail.com, adamobarros@gmail.com

(3) Queensland University of Technology, School of Earth, Environmental and Biological Sciences, Brisbane, Queensland, Australia.

(4) Associação Floresta Cheia Instituto de Conservação Ambiental, Rua b17, Residencial Recanto do Bosque, Goiânia, Goiás, Brazil.

Neto G.S.F., Barros A.C., Sobroza T.V., Neves P.U.C., Phillips M.J. \& Guimarães E.F. (2020) Period of the day and food-based enrichment affect behaviour activity of Tamandua tetradactyla in captivity? Pesquisa $e$ Ensino em Ciências Exatas e da Natureza, 4: e1498. http://dx.doi.org/10.29215/pecen.v4i0.1498

Academic editor: Manoel dos Santos Filho. Received: 17 June 2020. Accepted: 08 September 2020. Published: 12 September 2020.

Período do dia e enriquecimento alimentar afetam a atividade comportamental de Tamandua tetradactyla em cativeiro?

Resumo: Animais resgatados passam um período em cativeiro antes de serem devolvidos a natureza. Durante esse período em cativeiro é fundamental que os animais apresentem os comportamentos mais próximos dos apresentados na natureza, e enriquecimento ambiental é uma forma de assegurar o bem estar animal em cativeiro. O objetivo deste estudo foi i) descrever o repertório comportamental de indivíduos do tamanduá-mirim (Tamandua tetradactyla) (Ordem Pilosa), e determinar qual comportamento foi mais frequente; ii) avaliar o efeito do período diurno (06:00-18:00) e noturno (18:0005:59) na frequência dos comportamentos, e iii) comparar a porcentagem de comportamentos com e sem enriquecimento ambiental. Observações foram feitas utilizando o método de animal focal. Cinco machos e uma fêmea foram observados em pares para se observar as interações entre os indivíduos. Foram registrados 30 atos comportamentais distribuídos em seis categorias: locomoção, forrageio, alimentação, inatividade, limpeza corporal e interação. Geralmente, os comportamentos mais frequentemente observados foram locomoção e alimentação, geralmente durante o dia, exceto inatividade, que foi mais comum durante a noite. Esse resultado pode ser atribuído a maior atividade diurna do macho, enquanto as fêmeas são mais noturnas em cativeiro. Nossos resultados sugerem que o enriquecimento ambiental favorece maior bem-estar para os indivíduos em cativeiro através do aumento de comportamentos ativos como alimentação, interação e forrageio. Esse estudo provê uma lista de comportamentos que podem ser úteis em entender a etologia e aspectos relacionados à conservação, especialmente em cativeiro de $T$. tetradactyla.

Palavras chave: Enriquecimento ambiental, tamanduá-mirim, repertório comportamental, animal focal.

Abstract: Rescued animals spend some period in captivity prior to their release. During this period it is fundamental that animals present behaviours that closely match with behaviours presented in nature, and environmental enrichment is an often-applied tool to secure animal welfare in captivity. The goals of this study were i) to describe the behavioural repertoire of six captive individuals of lesser anteater (Tamandua tetradactyla) (Order Pilosa), and determine which behaviours were more common; ii) to compare the effect of daily (06:00-18:00) and nocturnal (18:00-05:59) periods in the activity pattern of the lesser anteater; and iii) to determine the effect of food-based enrichment in the frequency of behaviours of lesser anteater. 
During a year, six individuals of $T$. tetradactyla were monitored in pairs. An ethogram was prepared based on focal-animal observations for five males and one female. We recorded a total of 30 behavioural patterns in six categories: inactivity, feeding, foraging, locomotion, self-maintenance and interaction. Generally, the most frequently observed behaviours were locomotion and feeding, mainly during daylight hours, while inactivity was more common at night. This could be because the majority of our studied individuals were males, and males are more diurnal, while females are more nocturnal in captivity. Our results also suggest that food-based enrichment items enhance well-being for captive individuals by increasing active behaviours such as feeding, foraging and interaction. This study provides data that can be useful for management of the species in understanding the ethology of T. tetradactyla, especially for ex situ and in situ conservation efforts.

Key words: Environmental enrichment, lesser anteater, behavioural repertoire, focal-animal.

\section{Introduction}

Rescued animals often need to spend some period of time in a captive environment before they can be returned to their natural habitat (Melo \& Santos-Filho 2007). Captivity forces animals to be in an environment different from the natural ecological habitat (Baer et al. 2010). In such situations, animals usually have limited opportunities to perform certain behaviours due to space restrictions, absence of or different stimuli and limited nutritional options, which can increase stereotyped behaviours (Morgan \& Tromborg 2007), and most mammals tend to fatten due to less effort (Garland 1983). In the natural habitat, animals need to face many biotic and abiotic factors to be able to find food sources, defend themselves against predators, reproduce, and for some species defend their territories (Broom \& Johnson 1993). Behaviour evaluation is one of the main tools that allow researchers and technicians to assess the well-being of animals. Nonetheless, behavioural observations of captive animals can provide a valuable baseline for appropriate management and further ecological studies of species in the wild (Del-Claro 2010).

One way to increase behavioural diversity in captivity is by food-based and environmental enrichment (Hosey et al. 2013). Alimentary enrichment, for instance, changes how food sources are presented to animals, as well as providing food items that are similar to what would be found in natural habitats (Newberry 1995). Such activities provide physical and psychological improvements to animal welfare (Catapani et al. 2019). For example, responses to environmental enrichment improved the welfare and intensified the active behaviours of zoohoused lesser anteaters through adrenocortical activity (Eguizábal et al. 2013). In the wild, lesser anteaters are solitary, cryptic animals, and interact with conspecifics only occasionally for specific activities (Medri et al. 2006). In order to assess the impact of environmental enrichment, one of the first needs is to know how individuals behave in captivity in the absence of enrichment, and then test whether their behaviours change with enrichment (Sobroza \& Fortes 2018).

Ethograms have long provided a valuable tool for understanding the behaviour of animals in their natural habitats (Martin \& Bateson 1993). The goal of an ethogram is to define and quantify all the different types of behavioural patterns exhibited by individuals of a species (Del-Claro 2010). Ethograms exist for a great variety of taxonomic groups, including amphibians (Davis 2002), birds (Brown \& Veltman 1987; Porto \& Piratelli 2005), reptiles (Greenberg 1977; Shine \& Torr 1994), and mammals (Martin 1980; Albuquerque \& Codenotti 2006). Although mammals are probably the best-known group in terms of their natural behavioural patterns (Del-Claro 2010), there have been few studies of the lesser anteater, Tamandua tetradactyla (Linnaeus 1758) (Eguizábal et al. 2013; Catapani 2014; Eguizábal et al. 2019).

The lesser anteater, popularly known as tamanduá-mirim or tamanduá-de-colete, in Brazil (Tavares 2008), or Northern tamandua in English speaking countries or even oso melero in Spanish speaking countries, is a specialized mammalian myrmecophage species distributed across an area of more than $1.500 .000 \mathrm{~km}^{2}$ (Medri et al. 2006), comprising four subspecies (Wilson \& Reeder 2005). This species ranges from southern Mexico to northern Uruguay and Argentina (Superina et al. 2010), among habitats including gallery forests adjacent to savannas, 
and lowland and montane moist tropical rain forest (Eisenberg 1989), but also fragmented areas in the Brazilian Cerrado (Zimbres et al. 2013). Females gives birth to only one young per year, with the gestation ranging from four to five months (Silveira 1968). Mean individual home range size varies from 25 hectares in Ecuador (Tirira 2007) and 70 hectares in Panama (Eisenberg 1989) to 380 hectares in the llanos of Venezuela (Montgomery \& Lubin 1977).

In the wild, the lesser anteater rests in trees or burrows of armadillos and it is more active at night (Rodrigues et al. 2008), but in captivity these animals can be also active during the day (Montgomery 1985; Medri et al. 2006). T. tetradactyla is one of the most specialized predators of small and large nests of termites and ants, both on the ground and in trees contributing to ecosystem dynamics (Montgomery 1985). Though considered primarily arboreal, individuals may also move, feed and rest on the ground (Montgomery 1985; Rodrigues et al. 2008), and can also swim (Esser et al. 2010). When T. tetradactyla feels threatened, it assumes a tripod posture, formed by the hind legs and tail, with forelimbs extended and claws free for defense (Medri et al. 2006).

Little is known about the behavioural repertoire of Tamandua tetradactyla. This may have management implications because their populations are declining in their natural habitats due to threats, such as highway mortality, fire and illegal hunting (Ferreira da Cunha et al. 2010). The lesser anteater is a common victim of car-based wildlife accidents. Often these cause mortality (Pereira et al. 2006). When debilitated, animals are taken into captivity by environmental agencies such as the Wild Animals Triage Center (CETAS/IBAMA/Brazil). Also, lesser anteaters are often captured during wildlife rescues following wildfires, habitat fragmentation and habitat loss due to agriculture (Superina et al. 2010). Consequently, a large number of lesser anteaters are present in wildlife rescue centers (Pereira et al. 2006), which means that there is a need for behavioural studies that allow the animals to be cared for appropriately and their needs anticipated, as has been done for the giant anteater, Myrmecophaga tridactyla (Schmidt 2012).

The goals of this study were: i) to describe the behavioural repertoire of captive, rescued T. tetradactyla individuals; ii) to compare the effect of daily (06:00-18:00) and nocturnal (18:0005:59) periods in the activity pattern of the lesser anteater; iii) to determine the effect of foodbased enrichment in the frequency of behaviours of lesser anteater. In accordance with the behaviour of wild animals (Marques \& Fabián 2018), we expected that captive T. tetradactyla would be more nocturnal than diurnal, and with more active behaviours presented upon the introduction of food-based environmental enrichment. Also, we predicted that even in diurnal periods T. tetradactyla will increase active behaviours (e.g., foraging and feeding) with their enclosure enriched.

\section{Material and Methods}

\section{Housing}

The study was carried out at the Vale do Tamanduá farm (16 59'25.2" S, 49 $\left.24^{\prime} 17.2^{\prime \prime} \mathrm{W}\right)$, in Aragoiânia municipality, Goiás, west-central Brazil. It is a wildlife refuge that maintains enclosures for animals that need to spend time under care and is used by the Wild Animals Triage Center (CETAS/Intituto Brasileiro do Meio Ambiente) for screening and treating wild animals received via official confiscation, rescue or voluntary donation of illegally wild-captured individuals. The area inside and surrounding the enclosures are characteristic of Cerrado, and includes different types of Cerrado formations such as cerradão, gallery forest and open cerrado (Eiten 1978).

\section{Study individuals}

All observed T. tetradactyla individuals were rescued in the Goiás State in the Cerrado biome and had been checked by CETAS veterinarians before placement in the enclosure. In total, the group consisted of six animals: five males $(\mathrm{M})$ and one female $(\mathrm{F})$. Of the five males, 
one was an infant (2-3 months: M1), two were young males (9-15 months: M2, M3), and two were adults (24-60 months: M4, M5). The one female (F1) was young (12 months). Animals were easily recognized individually due to variation in coloration and body size. All animals were kept in pairs for two months prior to the observation sessions in enclosures with similar characteristics as the ones that we monitored. For the observation sessions, pairs of individuals were kept together in two enclosures of $2.72 \mathrm{~m} \times 2.40 \mathrm{~m} \times 3.94 \mathrm{~m}$, allowing the animals to interact with each other. We worked in pairs and the type of food sources were changed daily to create opportunities for social interactions and to mitigate the effects of space restrictions, and thus enhance welfare for this species (Catapani et al. 2019). Animals were fed every morning (06:00-07:00) with a mixture of ripe fruits (oranges, papaya, and banana) and eggs. There was permanent running water for drinking, and one large non-mobile aluminium feeder. Food material was refreshed continually. A thick paste composed of curds, broccoli or cabbage, dog food, assorted fruits, vegetables and boiled pig's liver was also provided. These ingredients were homogenized in a blender and provided to the animals in the feeders. The paste was developed by CETAS veterinarians and zoo technicians as a supplemental food for young and adult anteaters arriving at the center in a debilitated state.

\section{Behavioural sampling}

\section{Ethogram}

Preliminary observations were made in 2011 and behavioural sampling occurred between February 2012 and March 2013 (except for May and November 2012), during at least one weekend of each month, totalling 29 sampling days. Before monitoring, we randomized which individuals in each pair were going to be observed. We observed pairs of individuals because we were interested in social interactions, which are important from an animal welfare viewpoint. Because all animals were easily identified, we used focal-animal sampling in which all behaviour occurrences were recorded continuously during each sample period to evaluate the effects of both of the day period and environmental enrichment (Altmann 1974). Four observers switched between weekends and worked in pairs on two different enclosures that each contained a pair of animals. Descriptions and photographs of behaviours were thus made for four animals at the same time, but overall, all six individuals were monitored. We used this same procedure and follow the same ethogram for both behavioural sampling and environmental enrichment. Prior to collecting the data, all the observers trained together to minimize observer bias. We could see the entire enclosure. The observers made preliminary observations for the two months prior to data collection, and were therefore familiar with the identities of the subjects.

\section{Period of the day}

Adding up all hours of observing, animals were observed for a total of 280 hours, 173 hours during daylight (06:00-18:00; 62\% of survey) and 107 hours at night (18:00-05:59; 38\%). During sampling, two observers recorded behaviours per time period (night or day), standing some two meters from the enclosure, always concealed behind surrounding vegetation.

\section{Environmental enrichment}

In order to test the effects of environmental enrichment, we added to the enclosure a modified diet and modified environment, including terrestrial and arboreal termite mounds hidden in trees and vegetation, ripe fruits and eggs, as well as tree trunks with cavities that could be used as shelter. Soil and arboreal termites were taken from natural areas close to the enclosure. For this enrichment treatment we continued to work with two individuals for each per pair of observers. For the other enclosure, we only offered the routine diet, which was not hidden. We worked Saturdays and Sundays for two weekends (6 hours per day) with a total effort of 24 hours with enrichment and 24 hours without enrichment. This was done simultaneously in 
different enclosures, with two pairs of observers switched between weekends, both during the day and night. All six animals were submitted to this experiment. The study was non-invasive and complied with Brazilian law; authorization for the study was received from Cetas-Goiás.

\section{Data analyses}

To test whether $T$. tetradactyla activity is greater during night we used an unpaired twosample T-test using the sum of all the individual behaviours per category for all individuals. Data for both periods were standardized by sampling effort. We used the same test to evaluate the effects of environmental enrichment in the behaviour of animals. We also represented graphically the average number of behaviours per category without and with the introduction of enrichment items for all individuals with ggplot2 package (Wickham 2016). Statistical analyses were performed in $\mathrm{R}$ version 3.3.1 ( $\mathrm{R}$ Core Team 2016).

\section{Results}

Six broad behaviour categories were identified and described. Across 29 sampling days, six individuals of the captive $T$. tetradactyla displayed 30 different types of behaviours, with some photographic registers (Table 1, Figure 1). We classified a total of 2,113 total events in: feeding, foraging, inactivity, interaction, locomotion and self-maintenance. Summing the behaviours for all individuals, locomotion was the most common behavioural category $(42.09 \%$ - 887 behaviours), followed by feeding (24.85\% - 528 behaviours); inactivity (9.93\% - 209 behaviours); interaction ( $8.83 \%$ - 186 behaviours); self-maintenance $(8.3 \%-175$ behaviours) and foraging ( $6 \%$ - 128 behaviours; Table 2, Figure 2).

Active behaviours increased in the morning (see Table 3). For example, active behaviours such as feeding ( $\mathrm{t}$-test $=15.85 ; \mathrm{p}=0.008)$, interaction ( $\mathrm{t}$-test $=1.91 ; \mathrm{p}=0.05$ ), locomotion ( $\mathrm{t}$-test $=4.40 ; \mathrm{p}=0.001$ ) and maintenance $(\mathrm{t}$-test $=5.19 ; \mathrm{p}=0.04)$ increased, whereas inactivity behaviours ( $\mathrm{t}$-test $=-2.91 ; \mathrm{p}=0.001$ ) were more common at night. Foraging did not differ significantly (t-test $=4.66 ; \mathrm{p}=0.96)($ Figure 3$)$.

With the introduction of enrichment items we found that feeding ( $\mathrm{t}$-test $=3.64 ; \mathrm{p}=0.02$ ), interaction (t-test $=1.78 ; \mathrm{p}=0.03$ ) and foraging ( $\mathrm{t}$-test $=3.64 ; \mathrm{p}=0.02)$ increased, but there was a decrease in self-maintenance activities ( $\mathrm{t}$-test $=-2.19 ; \mathrm{p}=0.009$ ) (Figure 4). Locomotion ( $\mathrm{t}$-test $=$ $0.57 ; \mathrm{p}=0.64)$ and inactivity ( $\mathrm{t}$-test $=-3.50 ; \mathrm{p}=0.33)$ did not differ significantly.

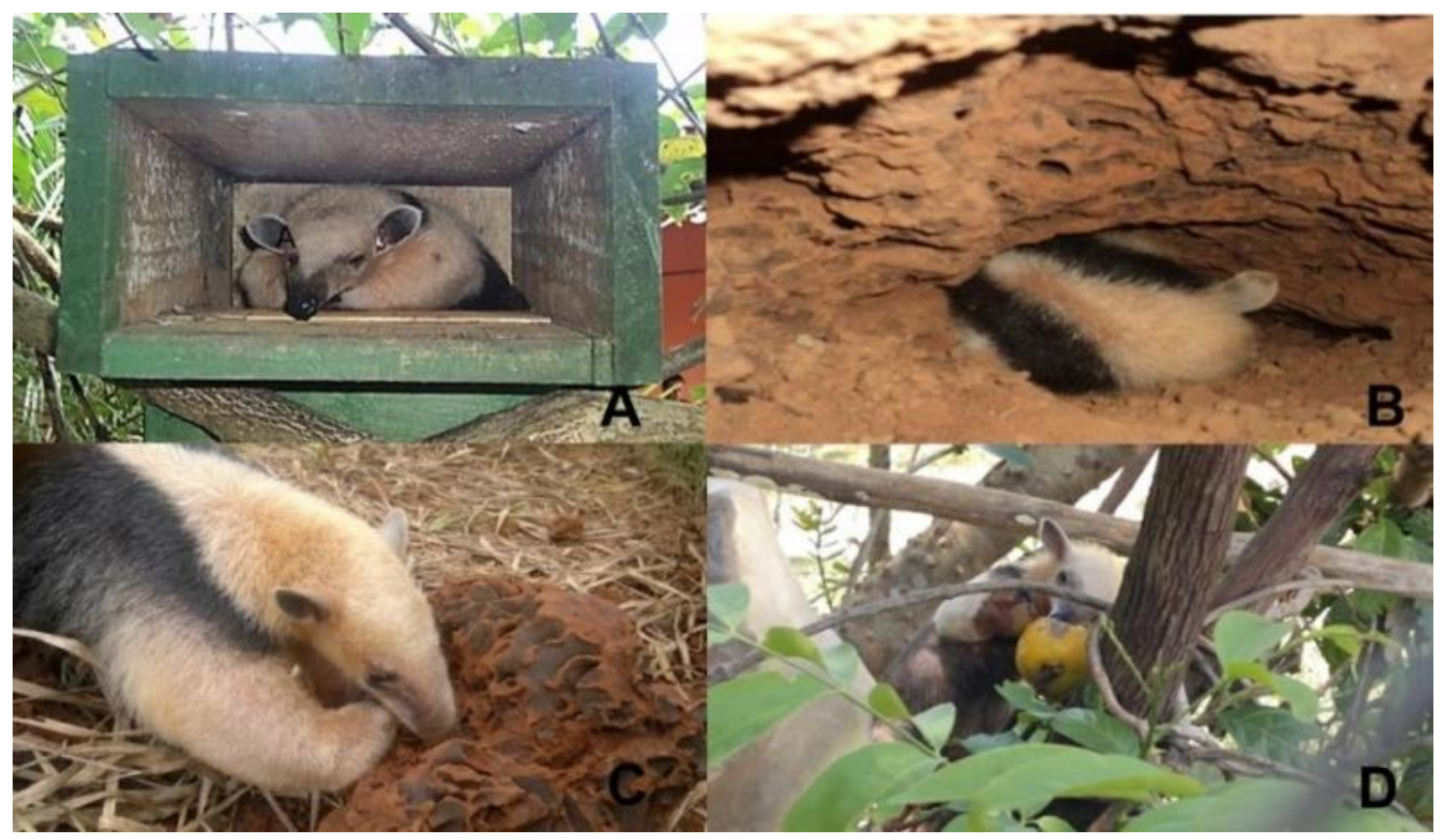

Figure 1. Examples of behaviours observed for captive Tamandua tetradactyla in West-Central Brazil: A. Resting; B. Sleeping; C. Feeding on terrestrial termite mounds; D. Feeding on the diet offered in the enclosure. 
Table 1. Description of observed behaviours and corresponding categories for six captive Tamandua tetradactyla in West-Central Brazil.

\begin{tabular}{|c|c|c|}
\hline Behaviour category & Activity & Description \\
\hline \multirow{5}{*}{ Locomotion } & Moving arboreally & $\begin{array}{l}\text { Individual moving in trees, on trunks, branches and other off-the- } \\
\text { ground structures in the enclosure. Individual moved using fore- } \\
\text { and hind-legs and the prehensile tail by hanging, climbing. }\end{array}$ \\
\hline & Moving terrestrially & $\begin{array}{l}\text { Individual moving on the ground, supported by all four limbs and } \\
\text { tail slightly raised or in contact with the ground. Activity began } \\
\text { with the movement of the limbs, leading to the horizontal } \\
\text { locomotion of the body. }\end{array}$ \\
\hline & Running & $\begin{array}{l}\text { Individual moving quickly, using the front and back limbs for } \\
\text { propulsion. During this time, the head remained horizontal to the } \\
\text { body plane, while the tail remained in contact with the ground. }\end{array}$ \\
\hline & Suspended & $\begin{array}{l}\text { Individual hanging vertically or horizontally from branches or } \\
\text { trunks during locomotion on these substrates. Individual used their } \\
\text { hind legs and tail or just the tail. Suspension sometimes occurred } \\
\text { upside down. Alternatively, the animal might grab another branch } \\
\text { soon after inversion and begin moving its head and forelegs in the } \\
\text { direction of interest. }\end{array}$ \\
\hline & Sliding & $\begin{array}{l}\text { Individual descending deliberately downwards vertically, clinging } \\
\text { with the fore-limbs and its tail onto an arboreal substrate always } \\
\text { head down. }\end{array}$ \\
\hline \multirow{4}{*}{ Foraging } & Digging & $\begin{array}{l}\text { Individual using the front paws with repeated movements to part } \\
\text { the soil, using limbs sequentially, pulling the soil toward the } \\
\text { ventral region of its body. }\end{array}$ \\
\hline & Scratching trunks & $\begin{array}{l}\text { Individual rubbing the trunk of living trees with front claws. } \\
\text { Animal stands vertically positioned with the tail holding a trunk or } \\
\text { twig. Head is tilted and directed at the substrate. After the event, } \\
\text { the substrate had several claw-made incisions from which exudates } \\
\text { flowed. The animal licks the exudate and rubs it on itself. }\end{array}$ \\
\hline & $\begin{array}{l}\text { Opening terrestrial } \\
\text { and arboreal termite } \\
\text { mounds }\end{array}$ & $\begin{array}{l}\text { Individual breaking open termite nests using the forelimbs and } \\
\text { claws to access the termites inside. }\end{array}$ \\
\hline & Olfactory investigation & $\begin{array}{l}\text { Individual exploring by sniffing some specific element of the } \\
\text { environment, such as a termite mound or the soil. During this } \\
\text { process, the head makes slow and short movements up and down. }\end{array}$ \\
\hline \multirow{6}{*}{ Feeding } & Drinking & $\begin{array}{l}\text { With the head facing the water source, legs and forelegs supported } \\
\text { on the ground or on the water source, individual introduces its } \\
\text { muzzle and tongue into the water. }\end{array}$ \\
\hline & $\begin{array}{l}\text { Feeding on terrestrial } \\
\text { termite mounds }\end{array}$ & $\begin{array}{l}\text { Individual introduces and moves its highly mobile and saliva- } \\
\text { covered tongue into a termite nest to obtain and ingest termites. } \\
\text { This act may be interspersed with opening termite mound } \\
\text { behaviour (Figure 1C). }\end{array}$ \\
\hline & $\begin{array}{l}\text { Feeding on arboreal } \\
\text { termite mounds }\end{array}$ & $\begin{array}{l}\text { Individual ingesting termites from nest in trunks of dead or living } \\
\text { trees. To do so, it uses its front claws to break open the termite } \\
\text { mounds located on the arboreal substrate, and the long tongue to } \\
\text { access the food source. This act usually occurs in arboreal strata, } \\
\text { and it is often undertaken with the support of the tail. The animal } \\
\text { is generally positioned vertically with the head up and the limbs } \\
\text { secured on the arboreal substrate. The animal can also position } \\
\text { itself with hind legs and tail secured on a branch, with forelegs and } \\
\text { trunk directed to the food source. }\end{array}$ \\
\hline & Feeding on ants & $\begin{array}{l}\text { Individual ingesting ants in the soil, using its claws to reach its } \\
\text { prey, remaining with all limbs on the soil and head facing the } \\
\text { substrate. }\end{array}$ \\
\hline & $\begin{array}{l}\text { Feeding on the diet } \\
\text { offered in the } \\
\text { enclosure }\end{array}$ & $\begin{array}{l}\text { Individual ingesting fruits, licking the pulp and other vegetables } \\
\text { after opening them with the front claws. With the four limbs on the } \\
\text { ground or arboreal substrate. Chicken eggs and prepared nutritious } \\
\text { paste were also consumed (Figure 1D). }\end{array}$ \\
\hline & Licking exudate & $\begin{array}{l}\text { Individual feeding on exudates, passing its tongue over cracks in } \\
\text { the tree trunk bark. As far as we know, this is the first record of this } \\
\text { behaviour for this species. }\end{array}$ \\
\hline
\end{tabular}


Table 1. Description of observed behaviours and corresponding categories for six captive Tamandua tetradactyla in West-Central Brazil (continued).

\begin{tabular}{|c|c|c|}
\hline Behaviour category & Activity & Description \\
\hline \multirow[t]{2}{*}{ Inactivity } & Resting & $\begin{array}{l}\text { Individual sheltered and resting, usually with the belly facing } \\
\text { downwards and limbs extended, with eyes partially closed (Figure } \\
\text { 1A). }\end{array}$ \\
\hline & Sleeping & $\begin{array}{l}\text { Individual is sheltered and resting, lying down, usually with the } \\
\text { limbs and muzzle facing the belly, with the back curved. Individuals } \\
\text { may also lay in hollows or inside termite mounds and remain } \\
\text { inactive for periods of three to } 12 \text { hours with eyes completely closed } \\
\text { (Figure 1B). }\end{array}$ \\
\hline \multirow{5}{*}{ Maintenance } & Cleaning & $\begin{array}{l}\text { Individual moistening its front claws with tongue and passing them } \\
\text { across snout, back or belly. Rarely, the tongue is placed directly on } \\
\text { these body parts. }\end{array}$ \\
\hline & Scratching & $\begin{array}{l}\text { Individual passing hind limb claws repeatedly over body-parts such } \\
\text { as head, snout, abdomen, limbs, back and tail. }\end{array}$ \\
\hline & Urinating & $\begin{array}{l}\text { Animal slightly lowering the posterior portion of their body, } \\
\text { urinating on trunks or soil. This act is performed both while } \\
\text { walking and when stopped. }\end{array}$ \\
\hline & Defecating & $\begin{array}{l}\text { With slight abduction of the hind limbs from the axis of the body } \\
\text { the animal eliminates feces. When defecating on branches, the tail } \\
\text { remains lightly attached to the supporting substrate. Animal may } \\
\text { commence locomotion while defecating. The act also occurred on } \\
\text { the ground, but in this case the tail remained slightly raised. }\end{array}$ \\
\hline & Sunbathing & $\begin{array}{l}\text { The animal actively seeks a place in the sun and remains on tree } \\
\text { substratum or soil. It will remain stationary, with the head slightly } \\
\text { inclined, in the sun for more than two hours, usually in the } \\
\text { morning. }\end{array}$ \\
\hline \multirow{6}{*}{ Interaction } & Play & $\begin{array}{l}\text { Two individuals approach and interact with each other by mutually } \\
\text { touching front legs or total body rolling following contact on the } \\
\text { ground. }\end{array}$ \\
\hline & Agonistic interaction & $\begin{array}{l}\text { Individuals adopt a tripod position, formed by the tail and hind } \\
\text { limbs, facing the possible opponent. Front limbs are in contact with } \\
\text { the other individual, presumably in an attempt to injure each other. }\end{array}$ \\
\hline & $\begin{array}{l}\text { Holding other } \\
\text { individual }\end{array}$ & $\begin{array}{l}\text { Young individuals use the hind limbs to hold onto the back of an } \\
\text { adult individual. }\end{array}$ \\
\hline & Touching & $\begin{array}{l}\text { Individuals touch or push another with the forepaws, accompanied } \\
\text { by olfactory inspection following touching. }\end{array}$ \\
\hline & Chasing & One animal continuously moves behind a second individual. \\
\hline & Standing up & $\begin{array}{l}\text { Adult male performs intense sniffing over an adult female upright } \\
\text { in the tripod stance. This action is performed when one male } \\
\text { follows a female, usually after the female had just urinated. }\end{array}$ \\
\hline
\end{tabular}

Table 2. Average percentage of total observed behaviours and corresponding categories performed for all individuals at the Vale do Tamanduá ranch, Aragoiânia, Goiás, Brazil. The behaviours were counted as the number of times a behaviour was observed divided by the total number of observed behaviours.

\begin{tabular}{llc}
\hline Behaviour category & Activity & Percentage \\
\hline & Moving arboreal & $16.46 \%$ \\
& Moving terrestrially & $24.65 \%$ \\
Locomotion & Running & $0.66 \%$ \\
& Suspended & $0.23 \%$ \\
& Sliding & $0.09 \%$ \\
\hline \multirow{3}{*}{ Foraging } & Digging & $0.14 \%$ \\
& Scratching trunks & $0.66 \%$ \\
& Opening terrestrial and arboreal termite mounds & $0.33 \%$ \\
& Olfactory investigation & $4.87 \%$ \\
\hline \multirow{2}{*}{ Feeding } & Drinking & $0.42 \%$ \\
& Feeding on terrestrial termite mounds & $11.21 \%$ \\
& Feeding on arboreal termite mounds & $2.31 \%$ \\
& Feeding on ants & $1.37 \%$ \\
& Feeding on the diet offered in the enclosure & $8.84 \%$ \\
& Licking exudate & $0.70 \%$ \\
\hline
\end{tabular}




\section{Behaviour activity of Tamandua tetradactyla}

Table 2. Average percentage of total observed behaviours and corresponding categories performed for all individuals at the Vale do Tamanduá ranch, Aragoiânia, Goiás, Brazil. The behaviours were counted as the number of times a behaviour was observed divided by the total number of observed behaviours (continued).

\begin{tabular}{llc}
\hline Behaviour category & Activity & Percentage \\
\hline Inactivity & Resting & $3.31 \%$ \\
& Sleeping & $6.62 \%$ \\
\hline & Cleaning & $0.18 \%$ \\
Self-maintenance & Scratching & $5.44 \%$ \\
& Urinating & $1.27 \%$ \\
& Defecating & $0.14 \%$ \\
& Sunbathing & $1.27 \%$ \\
& Play & $6.10 \%$ \\
Interaction & Agonistic interaction & $0.1 \%$ \\
& Holding other individual & $0.94 \%$ \\
& Touching & $0.52 \%$ \\
& Chasing & $0.33 \%$ \\
& Standing up & $0.56 \%$ \\
& Alert & $0.28 \%$ \\
\hline
\end{tabular}

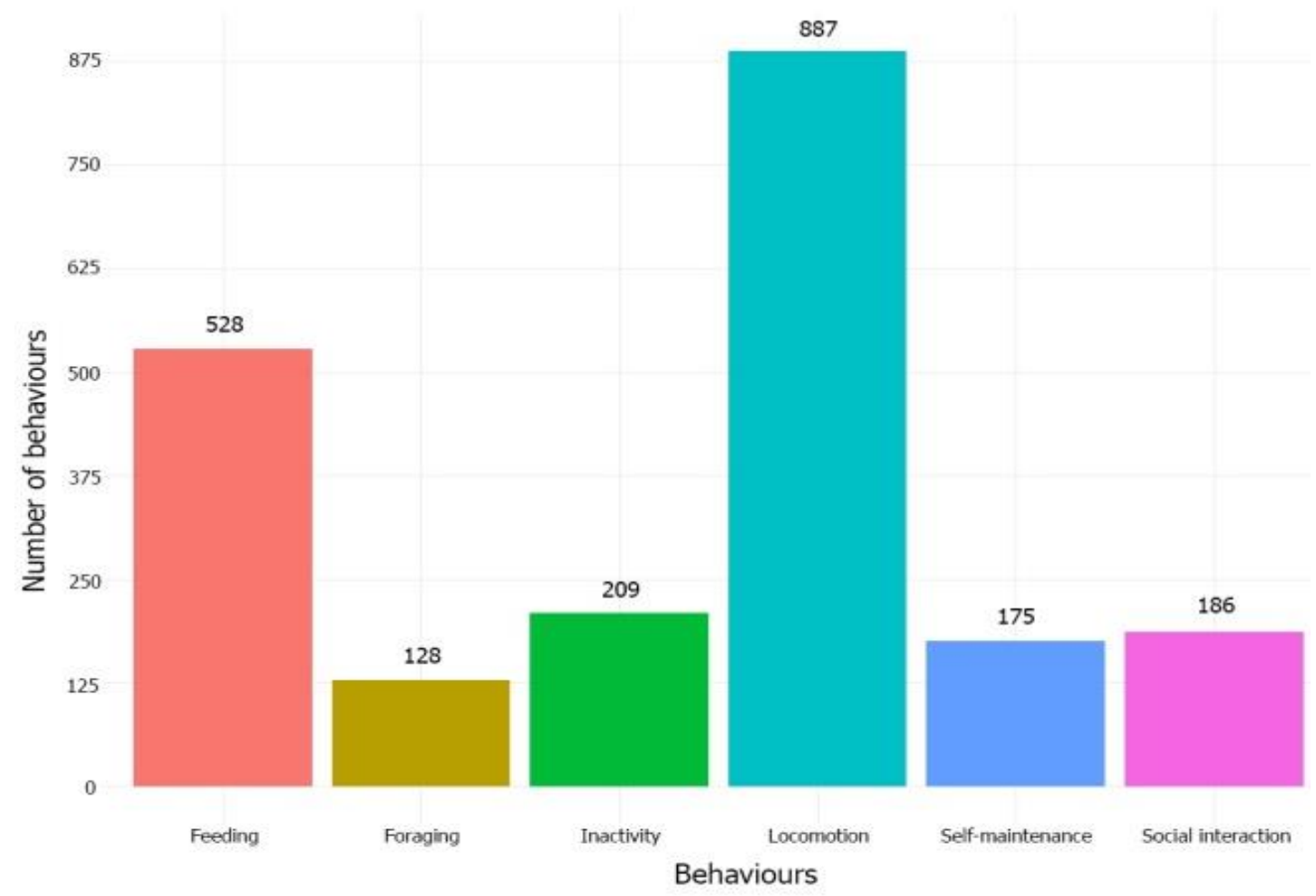

Figure 2. Number of behaviours per category. Numbers on top of the bar graph indicates the amount of behaviours sampled per category.

Table 3. Summary of T-test results on the effect of enrichment and period of the day on captive lesser anteaters behaviour $(\mathrm{N}=6)$. $\mathrm{SD}=$ Standard deviation.

\begin{tabular}{|c|c|c|c|c|c|c|c|c|c|c|c|c|}
\hline \multirow[b]{3}{*}{ Behaviours } & \multicolumn{6}{|c|}{ Enrichment } & \multicolumn{6}{|c|}{ Period of the day } \\
\hline & \multicolumn{2}{|c|}{ With } & \multicolumn{2}{|c|}{ Without } & \multicolumn{2}{|c|}{ Unpaired t-test } & \multicolumn{2}{|c|}{ Day } & \multicolumn{2}{|c|}{ Night } & \multicolumn{2}{|c|}{ Unpaired t-test } \\
\hline & Average & SD & Average & SD & $\mathbf{t}$ & $\mathbf{p}$ & Average & SD & Average & SD & $\mathbf{t}$ & $\mathbf{p}$ \\
\hline Locomotion & 26.67 & 3.82 & 25.33 & 3.54 & 0.57 & 0.64 & 31.50 & 4.50 & 11.00 & 1.00 & 4.40 & 0.001 \\
\hline Foraging & 15.00 & 6.40 & 6.67 & 1.80 & 3.64 & 0.02 & 4.00 & 1.00 & 2.50 & 0.50 & 4.66 & 0.96 \\
\hline Feeding & 12.50 & 4.11 & 4.33 & 2.87 & 3.64 & 0.02 & 19.50 & 1.50 & 5.00 & 1.00 & 15.85 & 0.008 \\
\hline Inactivity & 1.00 & 0.58 & 9.17 & 5.18 & -3.50 & 0.33 & 3.00 & 1.00 & 7.00 & 2.00 & -2.91 & 0.001 \\
\hline Maintenance & 2.33 & 1.89 & 5.83 & 3.02 & -2.19 & 0.009 & 6.50 & 1.50 & 1.50 & 0.50 & 5.19 & 0.04 \\
\hline Interaction & 2.50 & 0.96 & 1.33 & 1.11 & 1.78 & 0.03 & 6.00 & 2.00 & 2.93 & 1.07 & 1.91 & 0.05 \\
\hline
\end{tabular}




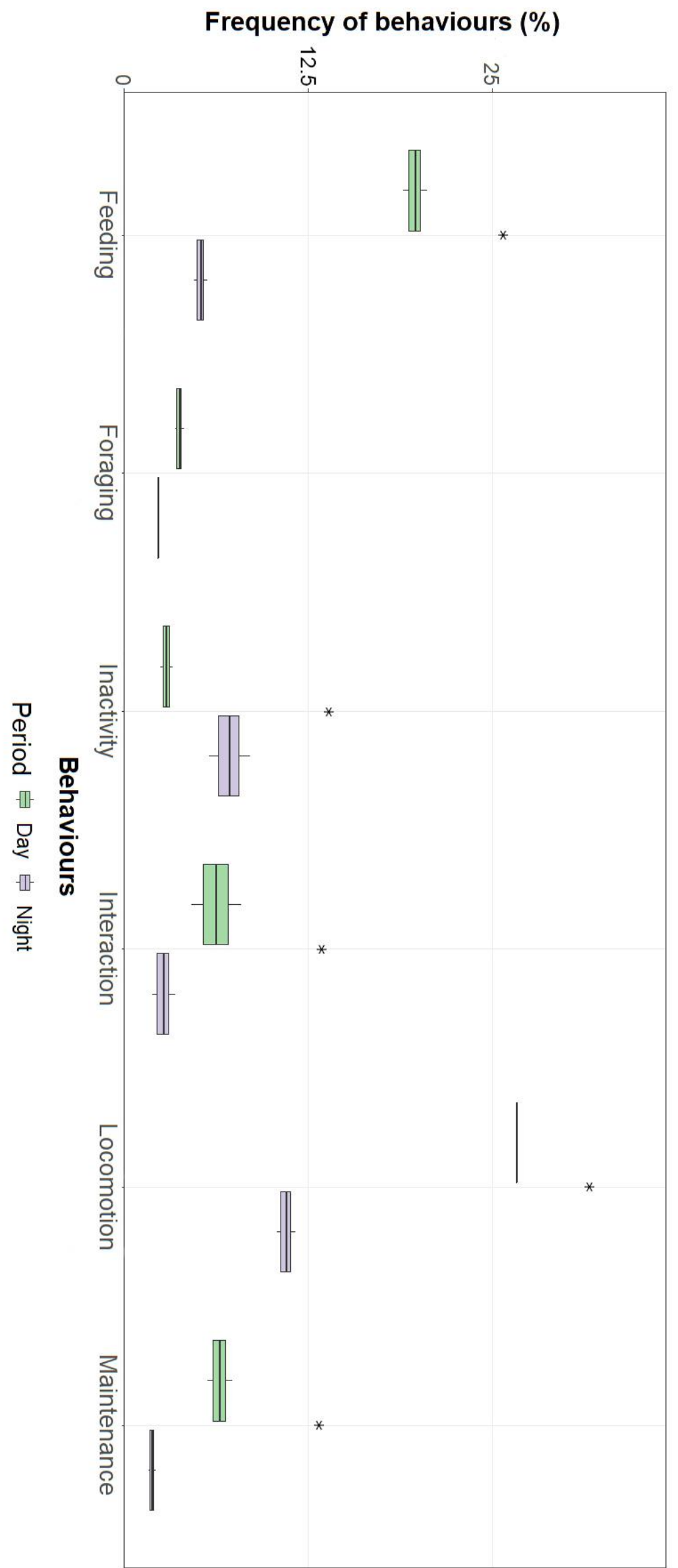

Figure 3. Frequency plots with y-axis indicating the frequency of behaviours, whereas the $\mathrm{x}$ axis is the sum of all behaviours for all individuals per category. Colour indicates the period of the day (green) and night (purple). $\left({ }^{*}\right)$ Indicates behaviours that differ significantly between day and night periods $(\mathrm{p}<0.05)$. 


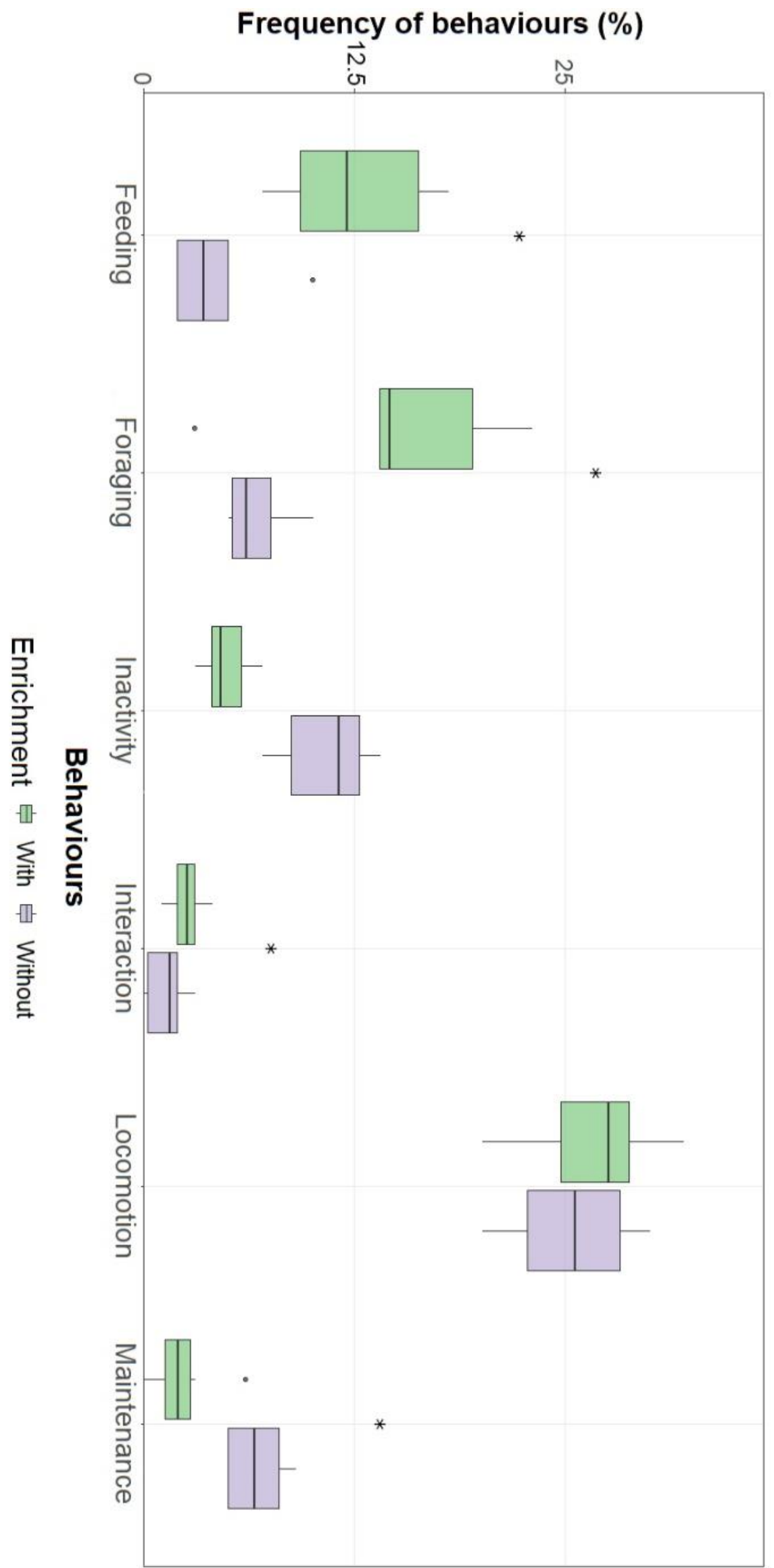

Figure 4. Frequency plots with the frequency of behaviours of all individuals per category with (green) and without (purple) the introduction of enrichment items in the enclosure. $\left.{ }^{*}\right)$ Indicates behaviours that differ significantly with and without enrichment $(p<0.05)$. 


\section{Discussion}

The most frequently observed behavioural categories in captivity were locomotion and feeding, but foraging, inactivity, interaction and self-maintenance were also recorded. Moving terrestrially $(24.65 \%)$ was the most common activity followed by moving arboreal $(16.46 \%)$ within the locomotion behavioural category. Locomotion in the wild could be related to searching for reproductive partners and increasing availability of food sources (Gallo et al. 2017; Trovati \& Brito 2009). Individuals of this species tend to move about $1 \mathrm{~km}$ per day (Trovati \& Brito 2009), but repetitive locomotion in captivity can also be a stereotype behaviour that future studies could work to decrease by stimulating natural behaviours such as interaction, foraging and feeding (Eguizábal et al. 2019). Feeding was also commonly recorded (almost a quarter of records), and included acts related to feeding on terrestrial (11.21\%) and arboreal (2.31\%) termite mounds. These feeding behaviours were also recorded commonly in captive giant anteaters, Myrmecophaga tridactyla, which frequently look for termites in mounds located within their enclosures (Andrade et al. 2009).

Social interactions and self-maintenance behaviours were also commonly recorded. Interactions between $T$. tetradactyla individuals were recorded in almost $9 \%$ of all the observed behaviours. One of the interaction activities observed involved one individual holding onto the back of another individual, an action that may be related to the age of the animal concerned (three months), and its possible need for activities approximating to maternal interaction (Catapani et al. 2019). This interaction was usually accompanied by a vocalization that was performed by the same infant. Cubs arriving in a captive environment are generally vulnerable and appear to find it difficult to adapt to feeding and maintaining body temperature (Pérez Jimeno 2003). Juvenile individuals emitted a repeated characteristic call for about two minutes, generally when the animal was looking for food. Usually the adults let the infant climb on them; similar adult-young interactions were reported by Catapani (2014). We also observed agonistic interactions $(0.1 \%)$ between juvenile males, behaviour also recorded in the wild, where the attack posture tends to be followed by aggressive movements to defend against predators (Araujo et al. 2015). We have not observed mating actions during the survey, possible due to the proportion of adult females (only one) in relation to males (five) in this study. One of the least observed behavioural categories was self-maintenance (body cleaning activities), which accounted for $8.3 \%$ of all behaviours. All observed individuals received medical care from veterinarians, and were exposed to sunlight. Thus, it is possible that the real percentage found in nature might be higher because free-living individuals are commonly infested with ectoparasites (Martins \& Guglielmone 1995).

Few studies have been undertaken in relation to how activity patterns for this species vary. While $T$. tetradactyla was found to be mostly nocturnal or crepuscular in the Cerrado (Rodrigues et al. 2001), here, counter to what we predicted, we found that these individuals were more active during the day. Individuals of captive $T$. tetradactyla increased significantly in most of the active behaviours such as feeding, interaction, locomotion and maintenance for the period of the day, whereas inactivity behaviours were more common at night. This could be because in the wild lesser anteaters are subject to different environmental pressures (predation and resource limitation), in relation to their conspecifics in the wild (Price \& Stoinski 2007). These results could also be explained because male individuals tend to have more diurnal behaviours, while females are more nocturnal in captivity (Eguizábal et al. 2019). Here, five of six studied individuals were males, and we confirmed that males are more active during the day, but more females would be needed to confirm their nocturnal activity pattern.

Behavioural activity of lesser anteater was also affected by food-based enrichment. We found increased activity among lesser anteaters, such as for feeding, foraging and interaction in captivity during the enrichment period, whereas maintenance behaviours were more common without food-based enrichment, and locomotion did not differ. These results could be an indicator of greater animal well-being, supporting the application for food-based enrichment for captive individuals (Eguizábal et al. 2013). This could imply that by adapting the enclosure with 
environmental and food-based enrichment, we can maximize natural behaviours and avoid repetitive stereotypic locomotion behaviours for the lesser anteater (Koontz \& Roush 1996). Thus, our results are consistent with environmental enrichment favouring greater well-being for captive individuals.

\section{Conclusion}

In this study, we i) compiled a behavioural repertoire for captive individuals, to determine the frequency of activities and found that locomotion and feeding were the most common behaviours for this species. ii) We found that the activity pattern of Tamandua tetradactyla individuals increases during the day, relative to the night period, especially feeding, interaction with other individuals, self-maintenance and locomotion, while inactivity was more common at night. iii) The pattern of activity increased with the introduction of enrichment items, and individuals preferred to forage, feed and interact more, while behaviour activities related to self-maintenance were more common without enrichment items. In providing an ethogram for the lesser anteater and indicating the pattern activity during day period and the introduction of enrichment items, the current article provides data that raise information in relation to the needs and the best practice for this species in captivity. We encourage future studies that involve a greater number of individuals and account for sex differences, to show a more accurate relationship between food-based enrichment, activity patterns and the behaviour of lesser anteaters.

\section{Acknowledgements}

We are mainly grateful to Beth and Telmo, owners of the area where the studies were conducted, for the facilities, financial support, and help for this work. We thank all our field collaborators, especially Marco Prado, Sandro Júnior, and the reviewers of this work, especially Geisa Naiara, Tânia Amorim, Renato Pereira, Vinícius Alvarenga and Dr. Fausto Nomura. We also recognize the Wild Animals Triage Center of Goiás (CETAS/IBAMA-GO) and its collaborators who were always willing to help. The manuscript has been reviewed by a native English speaker.

\section{References}

Albuquerque V.J.D. \& Codenotti T.L. (2006) Etograma de um grupo de bugios-pretos, Alouatta caraya (Humboldt, 1812) (Primates, Atelidae) em um habitat fragmentado. Revista de Etologia, 8: 97-107.

Altmann J. (1974) Observational study of Behaviour: sampling methods. Behaviour, 49: 227-266. https://doi.org/10.1163/156853974X00534

Andrade E.V., Avels E.S. \& Oliveira M.A.B. (2009) Padrão comportamental de Myrmecophaga tridactyla (L.) (Mammalia, Pilosa) em cativeiro no parque estadual Dois irmão, PE. IX Journey of teaching, research and extension, Recife, Pernambuco.

Araujo R.S.S., Costa M.C.N. \& Miranda F.R. (2015) Encontro agonístico entre dois tamanduásmirins (Tamandua tetradactyla) (Mammalia: Myrmecophagidae) na natureza. Edentata, 16: 78-80.

Baer C.K., Kleiman D.G. \& Thompson K.V. (2010) Wild mammals in captivity: Principles and techniques for zoo management. University of Chicago Press. https://doi.org/10.7208/chicago/9780226440118.001.0001

Broom D.M. \& Johnson K.G. (1993) Stress and animal welfare. London: Chapman \& Hall. 211 p.

Brown E.D \& Veltman C.J. (1987) Ethogram of the Australian magpie (Gymnorhina tibicen) in comparison to other Cracticidae and Corvus species. Ethology, 76: 309-333.

https://doi.org/10.1111/j.1439-0310.1987.tb00692 
Catapani M.L. (2014) Comportamento de tamanduá-mirim, Tamandua tetradactyla (Linnaeus, 1758) (Pilosa, Myrmecophagidae) em condições de cativeiro: implicações ao bem-estar. Dissertação (Programa de Pós-Graduação em Ecologia e Recursos Naturais). Universidade Federal de São Carlos, Centro de Ciências Biológicas e da Saúde, São Carlos.

Catapani M.L., Pires J.S.R. \& Vasconcellos A.D.S. (2019) Single-or Pair-Housed: Which Is Better for Captive Southern Tamanduas? Journal of Applied Animal Welfare Science, 22: 289-297. https://doi.org/10.1080/10888705.2018.1508352

Davis T. M. (2002) An ethogram of intraspecific agonistic and display Behaviour for the wandering salamander, Aneides vagrans. Herpetologica, 58: 371-382. https://doi.org/10.2307/3893373

Del-Claro K. (2010) Introdução à ecologia comportamental: um manual para o estudo do comportamento animal. Rio de Janeiro: Technical Books. 128 p.

Eguizábal G.V., Palme R.D., Villarreal C., Dal Borgo J., Di Rienzo A. \& Busso J.M. (2013) Assessment of adrenocortical activity and Behaviour of the collared anteater (Tamandua tetradactyla) in response to food-based environmental enrichment. Zoo Biology, 32: 632-640. https://doi.org/10.1002/zoo.21100

Eguizábal G.V., Palme R.M., Superina C.J., Asencio M.C., García C. \& Busso J.M. (2019) Characterization and correlations of Behavioural and adrenocortical activities of zoo-housed lesser anteaters (Tamandua tetradactyla). Zoo biology, 38: 334-342. https://doi.org/10.1002/zoo.21492

Eisenberg J.F. (1989) Mammals of the Neotropics. Volume 1. The Northern Neotropics: Panama, Colombia, Venezuela, Guyana, Suriname, French Guiana. Chicago: The University of Chicago Press. 449 p. https://doi.org/10.5860/choice.27-2723

Eiten G. (1978) Delimitation of the cerrado concept. Vegetatio, 36: 169-178. https://doi.org/10.1007/bf02342599

Esser H., Brown D. \& Liefting Y. (2010) Swimming in the northern tamandua (Tamandua mexicana) in Panama. Edentata, 11: 70-72. https://doi.org/10.1896/ 020.011.0112

Ferreira da Cunha H., Alves Moreira F.G. \& Sousa Silva S. (2010) Roadkill of wild vertebrates along the GO-060 road between Goiânia and Iporá, Goiás State, Brazil. Acta Scientiarum Biological Sciences, 32: 257-263. https://doi.org/10.4025/actascibiolsci.v32i3.4752

Gallo J.A., Abba L., Elizalde D.N., Ríos T.A. \& Ezquiaga M.C. (2017) First study on food habits of anteaters, Myrmecophaga tridactyla and Tamandua tetradactyla, at the southern limit of their distribution. Mammalia, 81: 601-604. https://doi.org/10.1515/mammalia-2016-0117

Garland T. (1983) Scaling the ecological cost of transport to body mass in terrestrial mammals. The American Naturalist, 121: 571-587. https://doi.org/10.1086/284084

Greenberg N. (1977) An ethogram of the blue spiny lizard, Sceloporus cyanogenys (Reptilia, Lacertilia, Iguanidae). Journal of Herpetology, 25: 177-195. https://doi.org/10.2307/1563139

Hosey G., Melfi V. \& Pankhurst S. (2013) Zoo animals: Behaviour, management and welfare. Oxford: Oxford University Press. 522 p.

Koontz F.W. \& Roush R. (1996) Communication and social behaviour (p. 334-343). In: Kleiman D.G., Allen M.E., Thompson K.V. \& Lumpkin S. (eds). Wild mammals in captivity: Principles and techniques. Chicago IL: University of Chicago Press. 656 p.

Marques R.V. \& Fabián M.E. (2018) Daily activity patterns of medium and large neotropical mammals in an area of Atlantic rain forest at altitude. Revista Brasileira de Zoociências, 19: 38-64. https://doi.org/10.34019/2596-3325.2018.v19.24736

Martin I.G. (1980) An ethogram of captive Blarina brevicauda. American Midland Naturalist, 1: 290-294. https://doi.org/10.2307/2424868

Martin P. \& Bateson P. (1993) Measuring behaviour: An introductory guide. Cambridge: Cambridge University Press. 222 p. https://doi.org/10.1002/bs.3830400109

Martins J.R. \& Guglielmone A.A. (1995) Registro de Amblyomma calcaratum parasitando Tamanduá mirim (Tamandua tetradactyla) no Rio Grande do Sul. Arquivo Brasileiro de Medicina Veterinária e Zootecnia, 47: 91-92. 
Medri I.M., Mourão G.M. \& Rodrigues F.H. (2006) Ordem Xenarthra (p. 71-99). In: Reis N.R., Perachi A.L., Petro W.A. \& Lima I. P. (Eds). Mamíferos do Brasil. Londrina: Universidade Estadual de Londrina. 437 p.

Melo E.S. \& Santos-Filho M. (2007) Efeitos da BR-070 na Província Serrana de Cáceres, Mato Grosso, sobre a comunidade de vertebrados silvestres. Revista Brasileira de Zoociências, 9: 185-192.

Montgomery G.G. (1985) Movements, foraging and food habits of the four extant species of neotropical vermilinguas (Mammalia; Myrmecophagidae). The Evolution and Ecology of Armadillos, Sloths, and Armadillos, G.G. Montgomery. Washington, DC: Smithsonian Institution Press.

Montgomery G.G. \& Lubin Y.D. (1977) Prey influences on movements of neotropical anteaters. In: Proceedings of the 1975 predator symposium. Volume 1. Missoula: Montana Forest and Conservation Experiment Station, University of Montana.

Morgan K.N \& Tromborg C.T. (2007) Sources of stress in captivity. Applied animal behaviour science, 102: 262-302. https://doi.org/10.1016/j.applanim.2006.05.032

Newberry R.C. (1995) Environmental enrichment: increasing the biological relevance of captive environments. Applied Animal Behaviour Science, 44: 229-243. https://doi.org/10.1016/0168-1591(95)00616

Pereira A.P., Andrade F.A \& Fernandes M.E.B. (2006) Dois anos de monitoramento dos atropelamentos de mamíferos na rodovia PA-458, Bragança, Pará. Boletim do Museu Paraense Emílio Goeldi Ciências Naturais, 1: 77-83.

Pérez Jimeno G. (2003) Crianza artificial y manejo reproductivo de los tamanduá (Tamandua tetradactyla) en el Jardín Zoológico de Rosario, Argentina. Edentata, 5: 24-28.

Porto G.R. \& Piratelli A. (2005) Ethogram of the Shiny Cowbird, Molothrus bonariensis Gmelin (Aves, Emberizidae, Icterinae). Revista Brasileira de Zoologia, 22: 306-312. https://doi.org/10.1590/S0101-81752005000200002

Price E.E. \& Stoinski T.S. (2007) Group size: Determinants in the wild and implications for the captive housing of wild mammals in zoos. Applied Animal Behaviour Science, 103: 255-264. https://doi.org/10.1016/j.applanim.2006.05.021

R Core Team (2016) R: A Language and Environment for Statistical Computing. R Foundation for Statistical Computing, Vienna, Austria. https://www.R-project.org.

Rodrigues F.H., Marinho-Filho J. \& Dos Santos H.G. (2001) Home ranges of translocated lesser anteaters Tamandua tetradactyla in the cerrado of Brazil. Oryx, 35: 166-169. https://doi.org/10.1046/j.1365-3008.2001.00162

Rodrigues F.H.G., Medri I.M., Miranda G.H.B., Camilo-Alves C. \& Mourão G. (2008) Comportamento e ecologia de tamanduás. A biologia do Xenarthra: 257-268.

Schmidt T.L. (2012) Ethogram of the giant anteater (Myrmecophaga tridactyla) in captivity: an experience in the Temaikèn Foundation. Edentata, 13: 38-49. https://doi.org/10.5537/020.013.0105

Shine R. \& Torr G. A. (1994) An ethogram for the small scincid lizard (Lampropholis guichenoti) Amphibia-Reptilia, 15: 21-34. https://doi.org/10.1163/156853894x00524

Silveira E.K.P. (1968) Notas sobre a história natural do tamanduá mirim (Tamandua tetradactyla chiriquensis J. A. Allen 1904, Myrmecophagidae), com referências à fauna do Istmo do Panamá. Velozia, 6: 9-31.

Sobroza T.V \& Fortes V.B. (2018) Environmental enrichment for captive capuchin monkeys (Sapajus spp.) using natural material. Revista Brasileira de Zoociências, 19: 47-58. https://doi.org/10.34019/2596-3325.2018.v19.24767

Superina M., Miranda F.R. \& Abba A. M. (2010) The 2010 anteater red list assessment. Edentata, 11: 96-114. https://doi.org/10.5537/020.011.0201

Tavares S.V. (2008) Ocorrência de Tamandua tetradactyla (LINNAEUS, 1758) (Xenarthra, Myrmecophagidae) no município de Itaqui, fronteira oeste do Rio Grande do Sul, Brasil. Biodiversidade Pampeana, 6: 30-33. 
Tirira D. (2007) Guía de Campo de los Mamíferos del Ecuador. Publicación especial sobre los mamíferos del Ecuador 6. Quito: Ediciones Murciélago Blanco. 576 p.

Trovati R.G \& Brito B.D. (2009) Nota sobre deslocamento e área de uso de tamanduá-mirim (Tamandua tetradactyla) translocado no Cerrado brasileiro. Neotropical Biology and Conservation, 4: 144-149. https://doi.org/10.4013/nbc.2009.43.04

Wickham H. (2016) ggplot2: elegant graphics for data analysis. New York: Springer. $260 \mathrm{p}$. https://doi.org/10.1007/978-3-319-24277-4

Wilson D.E. \& Reeder D.M. (2005) Mammal species of the world: a taxonomic and geographic reference. $3^{\circ}$ edition. Baltimore, Maryland: Johns Hopkins University Press. 2142 p.

Zimbres B., Furtado M.M., Jácomo A.T.A., Silveira L., Sollmann R., Tôrres N.M., Machado R.B. \& Marinho-Filho J. (2013) The impact of habitat fragmentation on the ecology of xenarthrans (Mammalia) in the Brazilian Cerrado. Landscape Ecology, 28: 259-269.

https://doi.org/10.1007/s10980-012-9832-2 